\title{
ACIDITY OF UNSTIMULATED SALIVA AND DENTAL PLAQUE IN ASTHMATICS, TREATED WITH INHALED CORTICOSTEROIDS AND LONG-ACTING SYMPATHICOMIMETICS
}

\author{
Emilia Karova ${ }^{1}$, George Christoff ${ }^{2}$ \\ 1) Department of Conservative Dentistry, Faculty of Dental Medicine, \\ 2) Department of Health Economics, Faculty of Public Health,
}

\section{SUMMARY:}

The number of asthmatics is continuously increasing all over the world. The aim of the study is to study the effect of different combinations of inhaled corticosteroids and longacting sympathicomimetics on salivary and plaque $\mathrm{pH}$ in asthmatics with mild persistent asthma. The effect of different quantities of lactose, as gustatory corrector in the inhalers, is traced out.

Thirty patients of both sexes, from 20 to 55 years old participated in the study. Salivary and plaque $\mathrm{pH}$ values are traced out in 30 minutes period after drug inhalation, at 6months interval.

It is found out that inhaled drugs cause significant decrease of initial salivary $\mathrm{pH}$ values, the lowest ones reported on first and fifth minute after the inhalation. The average salivary $\mathrm{pH}$ levels on the 30th minute remain significantly lower than initial ones.

Most considerable changes in $\mathrm{pH}$ values are registered for patients treated with Fluticasone propionate and Salmeterol.

Key words: asthma, inhaled corticosteroids, inhaled long-acting sympathicomimetics, plaque $\mathrm{pH}$, salivary $\mathrm{pH}$

\section{INTRODUCTION:}

Up-to-date treatment of bronchial asthma is connected with combinations of inhaled corticosteroids and long-acting sympathicomimetics, frequently containing gustatory correctors such as lactose. Their prolonged everyday use can lead to a reduction of unstimulated salivary flow rate because of the $\beta$-agonists and decrease in salivary and dental plaque pH. $[4,7,15,27]$

Dental caries is a chronic disease involving localized destruction of specific sites of tooth surface. It is a multifactorial dynamic process that is modified by protective factors.[15, 27-29]

The enamel surface is in a state of dynamic equilibrium with its local oral environment (plaque fluid and saliva), involving constant movement of ions in and out. As plaque $\mathrm{pH}$ drops under 6.5 a process of demineralization begins, followed by a concomitant process of remineralization till $\mathrm{pH}$ range of 5.5 is reached. pH range of 5.5 is known as critical of enamel because after reaching it only demineralization processes are taking place. Acid production in plaque depends on: type of carbohydrates (simple sugars and sucrose), microbial composition (acidogenic and aciduric microorganisms) and the level of diffusion of substrate in the plaque and the metabolic products out of it. When the plaque is with low thickness saliva can modify it with its buffering systems. As the plaque thickness grows saliva can't neutralize the acidity and $\mathrm{pH}$ levels remain low.[4, 6, 11, 14-16; 27-29]

There is little evidence in literature for the relation between saliva parameters and dental health in asthmatics and their treatment. Most of the studies are carried out on kids and the obtained results are contradictory. $[1,2,8,9,12,18$, $25,26,30,34,35]$

\section{MATERIAL AND METHODS:}

Thirty asthmatics of both sexes, from 20 to 55 years old, participate in the study. They suffer from mild persistent asthma and are systematically treated with combinations of inhaled corticosteroids and long-acting sympathicomimetics. All patients with accompanying diseases and treatment, affecting saliva quantity and acidity are excluded from the investigation. Those with bad oral hygiene and parodontal diseases are excluded as well.

The asthmatic patients are divided in three groups, according to their medication (Seretide - Fluticasone propionate + Salmeterol, Symbicort - Budesonide + Formoterol and Foster- Beclometasone + Formoterol). The active component in all devices is inhaled in a dry powder form. The investigated medications have different quantity of gustatory correctors - $12,5 \mathrm{mg}$ Lactose monohydrate in Fluticasone propionate + Salmeterol; $0.730 \mathrm{mg}$ Lactose monohydrate in Budesonide + Formoterol and no correctors in Beclometasone + Formoterol.

All patients have made two visits in a period of six months. In each visit we followed up $\mathrm{pH}$ levels of unstimulated saliva in the course of $30^{\text {th }}$ minutes after the inhalation of the medication. The patients expectorated in a 
container before the inhalation and on the $1^{\text {st }}, 5^{\text {th }}, 10^{\text {th }}, 20^{\text {th }}$ and $30^{\text {th }}$ minute after it. $\mathrm{pH}$ levels are measured by $\mathrm{pH}$ test strips, placed into the saliva sample for 10 seconds. Strip colour is compared with the testing chart available in the package of GC Saliva-Check BUFFER, GC EUROPE N.V.

Dental plaque $\mathrm{pH}$ levels are measured in the course of $30^{\text {th }}$ minutes after the inhalation of the medication as well - before the inhalation and on the $1^{\text {st }}, 5^{\text {th }}, 10^{\text {th }}, 20^{\text {th }}$ and $30^{\text {th }}$ minute after it. Measurements are made with Dental Beetrode NMPH3, WPI Germany GmbH i.G. and pH meter Hanna 211 at the distal surfaces of 14, 24, 34 и 44.

All patients have signed an informed consent.

Data analyses are conducted using statistical software program SPSS 15.0 and paired simple t-test.

\section{RESULTS:}

Inhalation of corticosteroids and long-acting sympathicomimetics reduces salivary $\mathrm{pH}$, especially on the first and fifth minute. Lowest $\mathrm{pH}$ levels are founded after the inhalation of Fluticasone propionate + Salmeterol (Seretide) on the first visit - on the $1^{\text {st }}$ minute 5.45 and on the $5^{\text {th }}$ minute - 5.5. Higher $\mathrm{pH}$ levels are reported for the other two medications on both visits - Beclometasone + Formoterol (Foster)- first and second visit -5.65 , Budesonide + Formoterol (Symbicort) - first visit - 5.7, second visit - 5.8. Only after inhalation of Fluticasone propionate + Salmeterol salivary $\mathrm{pH}$ levels remain under 6.00 for a period of 20 minutes in both visits.

Salivary $\mathrm{pH}$ levels grow up till the $30^{\text {th }}$ minute after the inhalation in both visits but the oral environment remains moderately acidic because $\mathrm{pH}$ doesn't exceed 6.2. Fig.1, Fig.2

Fig. 1 and Fig. 2. Comparison of salivary pH levels after the drug inhalation for each visit

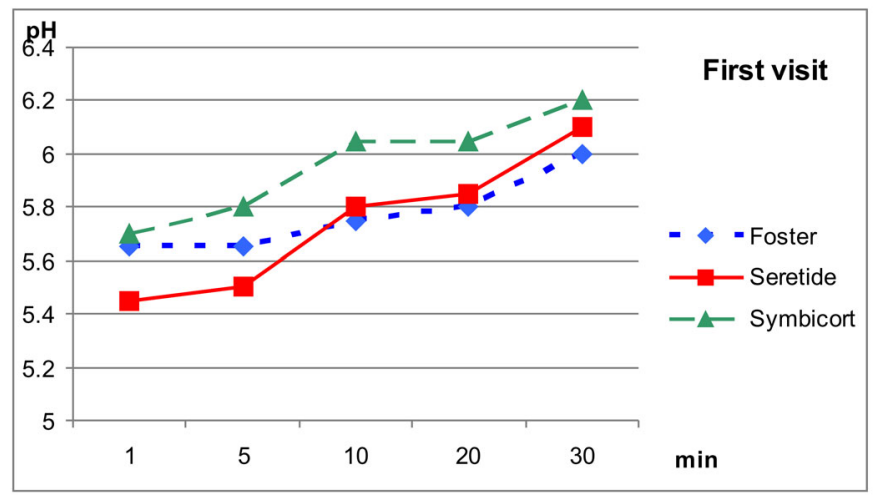

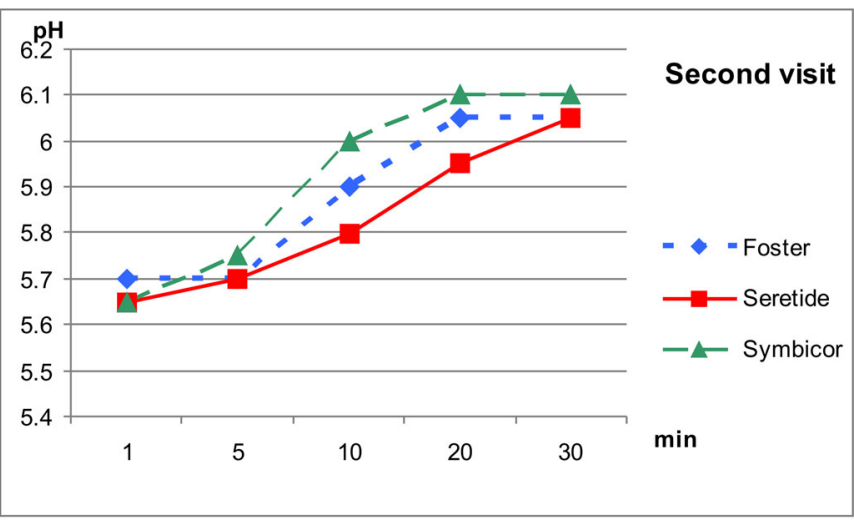

Comparison of initial salivary $\mathrm{pH}$ levels and these on the first and fifth minute indicates a significant decrease in both visits for each medication (paired simple t-test, $\mathrm{p}<0.001$ ).

Despite the observed tendency of increase of salivary $\mathrm{pH}$ levels till $30^{\text {th }}$ minute after drug inhalation, the results from the last measurements remain significantly lower when compared with the initial ones for each medicine on both visits (paired simple t-test, $\mathrm{p}<0.05$ ).

We followed up the effect of each drug on plaque $\mathrm{pH}$ as well. Once again, drug inhalation decreases plaque $\mathrm{pH}$, especially on the first and fifth minute. Lowest levels are registered after the inhalation of Fluticasone propionate + Salmeterol (Seretide) in all measurement of both visits, with the exception of that on the $30^{\text {th }}$ minute at the first visit. Highest plaque $\mathrm{pH}$ levels are found out after the inhalation of Beclometasone + Formoterol (Foster), but the differences are not statistically significant (paired simple t-test, $\mathrm{p}>0.05$ ).

A tendency of normalizing dental plaque acidity is observed. Highest $\mathrm{pH}$ levels are registered on the $30^{\text {th }}$ minute for all inhaled drugs. There is an insignificant increase of $\mathrm{pH}$ on the second visit when compared with the first one. Fig. 3, Fig. 4

Fig. 3 and Fig. 4. Comparison of plaque pH levels after the drug inhalation for each visit

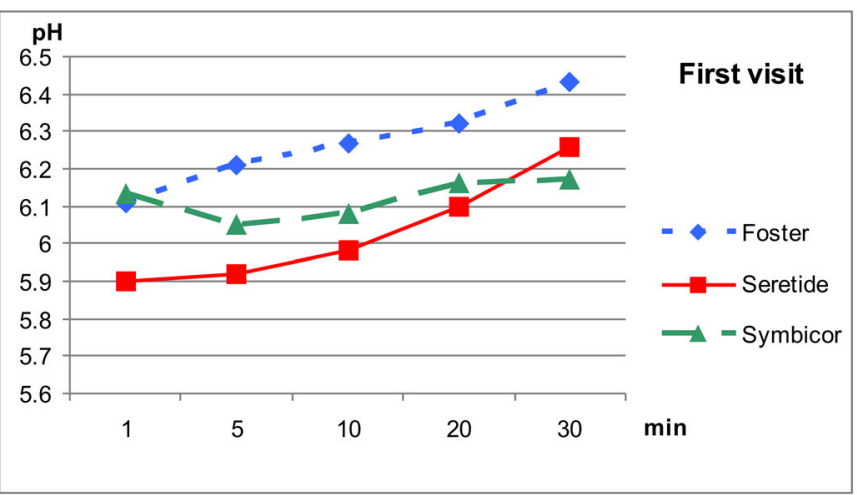




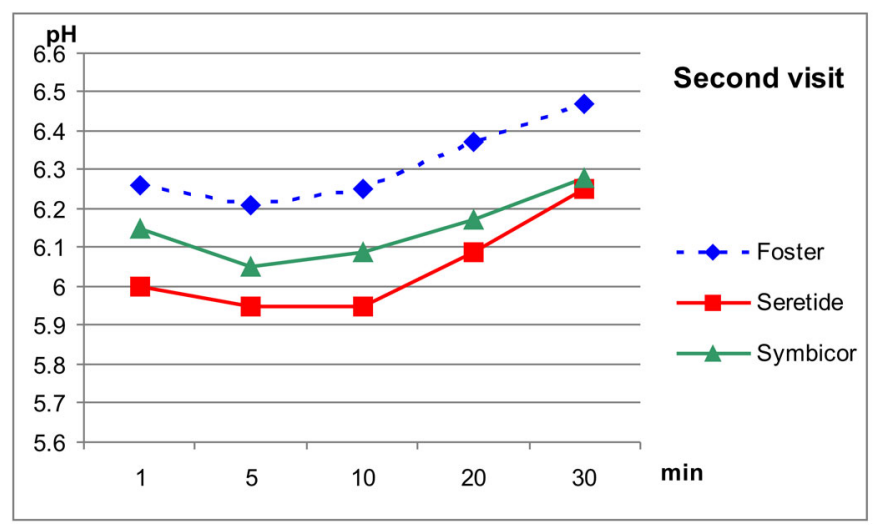

Drug inhalation decreases plaque $\mathrm{pH}$ levels on the first and fifth minute when compared with the initial measurements. We registered considerable differences in almost all comparisons $(\mathrm{p}<0.05)$. Table 1 .

Table 1. Comparison of initial plaque $\mathrm{pH}$ levels and $\mathrm{pH}$ on the $1^{\text {st }}$ and $5^{\text {th }}$ minute after drug inhalation

\begin{tabular}{|c|c|c|c|c|c|c|}
\hline \multirow{2}{*}{\multicolumn{3}{|c|}{ Inhaled drug }} & \multicolumn{3}{|c|}{ Group differences } & \multirow{3}{*}{$\begin{array}{c}\begin{array}{c}\text { Level of } \\
\text { importanc }\end{array} \\
<0.001\end{array}$} \\
\hline & & & \multirow{2}{*}{$\begin{array}{c}\text { Mean } \\
0,48\end{array}$} & \multirow{2}{*}{$\begin{array}{c}\text { Std. Dev. } \\
0,21\end{array}$} & \multirow{2}{*}{$\begin{array}{c}\text { Std. Error } \\
\text { Mean }\end{array}$} & \\
\hline Foster & I visit & Initial $\mathrm{pH}-\mathrm{pH}$ 1st minute & & & & \\
\hline & & Initial $\mathrm{pH}-\mathrm{pH}$ 5th minute & 0,39 & 0,31 & 0,10 & 0.003 \\
\hline & II visit & Initial $\mathrm{pH}-\mathrm{pH}$ 1st minute & 0,40 & 0,31 & 0,10 & 0.002 \\
\hline & & Initial $\mathrm{pH}-\mathrm{pH}$ 5th minute & 0,45 & 0,23 & 0,07 & $<0.001$ \\
\hline \multirow[t]{4}{*}{ Seretide } & \multirow[t]{2}{*}{ I visit } & Initial pH - pH 1st minute & 0,44 & 0,52 & 0,17 & 0.026 \\
\hline & & Initial $\mathrm{pH}-\mathrm{pH}$ 5th minute & 0,41 & 0,66 & 0,21 & 0.080 \\
\hline & \multirow[t]{2}{*}{ II visit } & Initial $\mathrm{pH}$ - $\mathrm{pH}$ 1st minute & 0,45 & 0,27 & 0,08 & $<0.001$ \\
\hline & & Initial $\mathrm{pH}-\mathrm{pH}$ 5th minute & 0,49 & 0,33 & 0,10 & 0.001 \\
\hline \multirow[t]{4}{*}{ Symbicort } & \multirow[t]{2}{*}{ I visit } & Initial $\mathrm{pH}-\mathrm{pH}$ 1st minute & 0,29 & 0,44 & 0,14 & 0.064 \\
\hline & & Initial $\mathrm{pH}-\mathrm{pH}$ 5th minute & 0,36 & 0,52 & 0,16 & 0.053 \\
\hline & \multirow[t]{2}{*}{ II visit } & Initial $\mathrm{pH}-\mathrm{pH}$ 1st minute & 0,32 & 0,20 & 0,06 & 0.001 \\
\hline & & Initial $\mathrm{pH}-\mathrm{pH}$ 5th minute & 0,43 & 0,26 & 0,08 & 0.001 \\
\hline
\end{tabular}

The average plaque $\mathrm{pH}$ levels registered on the $30^{\text {th }}$ minute are lower than initial ones on both visits for each drug. Significant differences are found out only after inhalation of Fluticasone propionate + Salmeterol (Seretide) on the second visit (paired simple t-test, $\mathrm{p}=0.039$ ).

\section{DISCUSSION:}

Combinations of inhaled corticosteroids and longacting sympathicomimetics cause similar changes in salivary and plaque $\mathrm{pH}$. Initial $\mathrm{pH}$ values sharply drop on the first and fifth minute after the inhalation and in almost all comparisons we found out significant differences. This process is followed by a tendency of gradual increase of $\mathrm{pH}$ up to the $30^{\text {th }}$ minute. Nevertheless, oral environment remains moderately acidic and doesn't reach initial $\mathrm{pH}$ levels. Statistically important differences are registered when the first and last $\mathrm{pH}$ measurements are compared.

We assume that the changes in acidity can be explained with the local effect of inhaled long-acting sympathicomimetics on salivary glands secretion. The reduced salivary flow rate influences negatively its buffering and clearing abilities.[1, 2, 5, 21-24] Drug gustatory correctors, such as sucrose, additionally decrease salivary and plaque $\mathrm{pH}$.

At the same time lower $\mathrm{pH}$ values are expected in asthmatics with gastro-esophageal reflux. [19]

As we expected, drugs with greatest quantity of lactose as gustatory correctors decrease most sharply salivary and plaque $\mathrm{pH}$ values. On the other hand, the active ingredient in 
the examined drugs is in a powder form and is easily adhered and kept on the tooth surface after the inhalation. The combination of these two factors and the necessity of everyday treatment in asthmatics will increase caries risk for these patients.[7, 19, 33]

Kargul et al. achieve similar results. They find out significant decrease in salivary and plaque $\mathrm{pH}$ after inhalation of different drugs $(p<0,001)$. They attribute these findings to the drug composition and not to the disease itself. [10]

Tootla et al. study the effect of 14 inhaler drugs on plaque $\mathrm{pH}$ but don't find lower $\mathrm{pH}$ values than 6.0. The DPI inhaler devices containing lactose decrease at greatest degree and for longest time the $\mathrm{pH}$ levels $(\mathrm{p}<0.05)$ which increases the risk for hard dental tissues.[33]

The same team establishes significant decrease of salivary quantity and $\mathrm{pH}$, measured in the course of 30 minutes after drugs' inhalation. [32, 33]

Other scientists $[5,23]$ state greater salivary acidity with the prolonged drug intake.

C. Sag et al. trace out the effect of fluticasone propionate $100 \mathrm{mcg}$ and salmeterol $50 \mathrm{mcg}$ in asthmatic children under the age of 7-17 years. They consider that these children need special dental care because of their continuous treatment.[23]

Information about increased caries risk and the influence of gustatory correctors in inhaler drugs on plaque $\mathrm{pH}$ can be found in the study of I. Roberts and S. Sunitha as well. [20,31]

Other scientists, such as M. Lenander-Lumikari et al. [13] don't find out critical $\mathrm{pH}$ levels after drug inhalation in any patients' group. However, they presume increased caries risk in asthmatics treated with inhaled corticosteroids, containing lactose.

At the same time we find articles in accordance of which prescribed inhaler drugs do not affect substantially oral environment. $[3,8,17]$

\section{CONCLUSIONS:}

- Inhalation of different combinations of corticosteroids and long-acting sympathicomimetics decreases initial salivary and plaque $\mathrm{pH}$, especially on first and fifth minute. It is followed by a tendency of increase of $\mathrm{pH}$ values up to the $30^{\text {th }}$ minute without reaching the initial levels.

- The average salivary $\mathrm{pH}$ levels on the $30^{\text {th }}$ minute remain significantly lower than initial ones.

- Combination of Fluticasone propionate and Salmeterol decreases salivary and plaque $\mathrm{pH}$ most substantially and for longest time. Prolonged use of drugs with greater quantities of lactose as gustatory correctors increases caries risk for asthmatics.

\section{REFERENCES:}

1. Bjerkeborn K, Dahllof G, Hedlin G, Lindell M, Modeer T. Effect of disease severity and pharmacotherapy of asthma on oral health in asthmatic children. Scand J Dent Res. 1987 Apr; 95(2):159-164. [PubMed]

2. Blume A, G. Viergutz, G. Hetzer, The Dental Health Status of Asthmatic german Children and Adolescents, Caries Res. 2001; 35:297/99 A

3. del-Rio-Navarro BE, CoronaHernandez L, Fragoso-Rios R, Berber A, Torres-Alcantara S, Cuairan-Ruidiaz $\mathrm{V}$, et al. Effect of salmeterol and salmeterol plus beclomethasone on saliva flow and $\operatorname{IgA}$ in patients with moderate-persistent chronic asthma, Ann Allergy Asthma Immunol. 2001; Nov;87(5):420-423. [PubMed]

4. Edgar WM. Duration of response and stimulus sequence in the interpretation of plaque $\mathrm{pH}$ data, $J$ Dent Res. 1982 Oct;61(10):1126-1129. [PubMed] [CrossRef]

5. Ersin NK, Gulen F, Eronat N, Cogulu D, Demir E, Tanac R, et al. Oral and dental manifestations of young asthmatics related to medication, severity and duration of condition. Pediatr Int. 2006 Dec;48(6):549-54. [PubMed] [CrossRef]

6. Geddes DA. Acids produced by human dental plaque metabolism in situ, Caries Res. 1975; 9(2):98-109. [PubMed]

7. Ginty J. Astma medication and caries. Br Dent J. 1997 Feb 8;182(3):88. [PubMed]

8. Hyyppa T, Paunio K. Oral health and salivary factors in children with asthma. Proc Finn Dent Soc. 1979; 75(1-2):7-10. [PubMed]

9. Kankaala TM, Virtanen JI, Larmas MA. Timing of first fillings in the primary dentition and permanent first molars of asmathic children. Acta Odontol Scand. 1998 Feb;56(1):20-24. [PubMed]

10. Kargul B, Tanboga I, Ergeneli S, Karakoc F, Dagli E. Inhaler medicament effects on saliva and plaque $\mathrm{pH}$ in asthmatic children. J Clin Pediatr Dent.
1998 Winter;22(2):137-140. [PubMed]

11. Larmas M. Saliva and dental caries: diagnostic tests for normal dental practice, Int Dent J. 1992 Aug;42(4): 199-208. [PubMed]

12. Laurikainen $K$, Kuusisto P. Comparison of the oral health status and salivary flow rate of asthmatic patients with those of nonastmatic adults-results of a pilot study. Allergy 1998 Mar;53(3): 316-319. [PubMed]

13. Lenander-Lumikari M, Soderling E, Loimaranta V, Ampula L, Effect of Inhaled Corticosteroids on Plaque $\mathrm{pH}$. Caries Res. 2000; 34:348

14. Loesche WJ. Role of Streptococcus mutans in human dental decay. Microbiol Rev. 1986 Dec;50(4): 353380. [PubMed]

15. Mandel ID. The role of saliva in maintaining oral homeostasis, $J$ Am Dent Assoc. 1989 Aug;119(2):298-304. [PubMed]

16. Margolis HC, Moreno EC. Composition and cariogenic potential of dental plaque fluid. Crit Rev Oral Biol 
Med. 1994, 5(1):1-25 [PubMed]

17. Mazzoleni S, Stellini E, Cavaleri E, Angelova Volponi A, Ferro R, Fochesato Colombani S. Dental caries in children with asthma undergoing treatment with short-acting beta2agonists. Eur J Paediatr Dent. 2008 Sep;9(3):132-8. [PubMed]

18. McDerra EJ, Pollard MA, Curzon ME. The dental status of asthmatic British school children. Pediatr Dent. 1998 Jul-Aug;20(4):281287. [PubMed[

19. O'Sullivan EA, Curzon MEJ. Drug treatments for asthma may cause erosive tooth damage. BMJ. $1998 \mathrm{Sept}$ 19;317(7161):820.

[PubMed]

[CrossRef]

20. Roberts IF, Roberts GJ. Relation between medicines sweetened with sucrose and dental disease, $\mathrm{Br}$ Med $J$. 1979 Jul 7;2(6181):14-16 [PubMed]

21. Ryberg M, Moller C, Ericson T. Effect of beta-adrenoreceptor agonists on saliva protein and dental caries in asthmatic children. J Dent Res. 1987 Aug;66(8):1404-1406. [PubMed] [CrossRef]

22. Ryberg M, Moller C, Ericson T. Saliva composition and caries development in asthmatic patients treated with beta2-adrenoreceptor agonists: a 4-year follow-up study. Scand J Dent Res. 1991 Jun;99(3):212-218. [PubMed]

23. Sag C, Ozden FO, Acikgoz G, Anlar FY. The effects of combination treatment with a long-acting beta2agonist and a corticosteroid on salivary flow rate, secretory immunoglobulin A, and oral health in children and adolescents with moderate asthma: a 1-month, single-blind clinical study, Clin Ther. 2007 Oct;29(10):2236-42. [PubMed] [CrossRef]

24. Shashikiran ND, Reddy VV, Raju PK. Effect of antiasthmatic medication on dental disease: dental caries and periodontal disease. J Indian Soc Pedod Prev Dent. 2007 Apr-Jun; 25(2):65-8. [PubMed] [CrossRef]

25. Shaw L, al-Dlaigan YH, Smith A. Childhood asthma and dental erosion. ASDC J Dent Child. 2000 MarApr;67(2):102-6, 82. [PubMed]

26. Shulman JD, Taylor SE, Nunn ME. The Association between Asthma and Dental Caries in Children and Adolescents: A Population-Based CaseControl Study. Caries Res. 2001 JulAug; 35(4):240-246. [PubMed] [CrossRef]

27. Sreebny LM. Saliva in health and disease: an appraisal and update. Int Dent J. 2000 Jun;50(3):140-161. [PubMed]

28. Stephan RM. Changes in hydrogen-ion concentration on tooth surfaces and in carious lesions. $J \mathrm{Am}$ Dent Assoc. 1940; 27:718-723

29. Stephan RM: Intra-oral hydrogen-ion concentrations associated with dental caries activity. J Dent Res.
1944; 23:257-266

30. Storhaug K. Caries experience in disabled pre-school children, Acta Odontol Scandin. 1985 Aug; 43(4):241248. [PubMed]

31. Sunitha S, Prashanth GM, Shanmukhappa, Chandu GN, Subba Reddy VV. An analysis of concentration of sucrose, endogenous $\mathrm{pH}$, and alteration in the plaque $\mathrm{pH}$ on consumption of commonly used liquid pediatric medicines. J Indian Soc Pedod Prev Dent. 2009 Jan-Mar;27(1): 44-48. [PubMed] [CrossRef]

32. Tootla R, Duggal MS, Toumba KJ. Comparison of Salivary pH Changes between Aerosol Metered-Dose and Dry Powder Asthma Inhalers. Caries Res. 2001; 35:297/100 A

33. Tootla R, Toumba KJ, Duggal MS. An evaluation of the acidogenic potential of asthma inhalers. Arch Oral Biol. 2004 Apr;49(4):275-28. [PubMed] [CrossRef]

34. van Leeuwen A, Zwaan CL. Do inhalation medicines have an effect on caries activity?. Ned Tijdschr Tandheelkd. 1999 Jul;106(7):279. [Article in Dutch] [PubMed]

35. Zhu JF, Hidalgo HA, Holmgreen WC, Redding SW, Hu J, Henry RJ. Dental management of children with asthma. Pediatr Dent. 1996 SepOct;18(5):363-70. [PubMed]

\section{Corresponding author:}

Dr. Emilia Goshova Karova

Department of Conservative dentistry, Faculty of Dental Medicine, MU - Sofia

1, St. G.Sofiiski Blvd., 1431 Sofia, Bulgaria

e-mail: karova_e@yahoo.com 